\title{
SPACE SYSTEMS - A NEW CRITICAL INFRASTRUCTURE SECTOR?
}

\author{
Cristian BAHNAREANU, Ph.D. \\ Senior Researcher, Centre for Defence and Security Strategic Studies, \\ "Carol I" National Defence University, Bucharest, Romania. \\ E-mail: cristi.bahnareanu@gmail.com
}

\begin{abstract}
In recent years, space capabilities have become increasingly important for the proper function and development of the economy and society and for ensuring security. Space is the newest operating environment for military powers, so decision makers can no longer ignore the benefits of space systems and technologies, but also the risks and threats they may be subjected to. The paper highlights the the growing contribution of all these space systems to the functioning of most critical infrastructure sectors and assesses that they must be an independent sector of such infrastructures that need to be protected.
\end{abstract}

Keywords: space systems; critical infrastructures; national security; protection and resilience.

In recent years, major economic and military powers have developed a major interest in the development of space systems and technologies and their use to increase the effectiveness of actions and missions in pursuing national interests. The United States, Russia and, more recently, China and the European Union, share their supremacy in space, a particularly important area in terms of applicability in civilian, commercial and military environments, especially communications, navigation, data transfer, astronomy, space exploration and monitoring, etc.

Space and space systems are vital to national security and the ability to understand emerging threats, to conduct operations and project power, to support political and diplomatic efforts, and to enable economic viability (US Department of Defense January 2011, 1). The space systems will soon become part of critical infrastructures, given the fact that they are integrated into almost all key sectors, whether we are talking about the economy and society or national security.

\section{Critical infrastructure - some theoretical considerations}

The concepts of infrastructure and critical infrastructure have been the subject of significant debate by decision-makers and the public, especially in United States, since the Cold War. After a long evaluation and re-evaluation process, the US Congress adopted the USA Patriot Act of 2001 (US Congress 2001, 401), which provided a new critical infrastructures definition: "systems and assets, whether physical or virtual, so vital to a country that the incapacity or destruction of such systems and assets would have a debilitating impact on security, national economic security, national public health or safety, or any combination of those matters". The 2002 National Strategy for Homeland Security (US Office of Homeland Security 2002, 29-30) reaffirms the definition of critical infrastructure and sets out the reasons why certain infrastructures are classified as critical, especially because of the functions or services they provide to the country, but also because of the complexity of those systems - the effects of a terrorist attack can spread far beyond the direct target, and reverberate long after the immediate damage.

The 2003 Homeland Security Presidential Directive 7 on Critical Infrastructure Identification, Prioritization, and Protection (The White House 2003) adopts the same 
STRATEGIES XXI International Scientific Conference

The Complex and Dynamic Nature of the Security Environment

definition of critical infrastructures provided by USA Patriot Act and the classification of critical infrastructures and key assets (13 sectors) stipulated in the 2003 National Strategy for the Physical Protection of Critical Infrastructure and Key Assets (The White House 2003, 3679). About 10 years later, the 2013 Presidential Policy Directive 21 on Critical Infrastructure Security and Resilience (The White House 2013) extends critical infrastructures to 16 sectors: Chemical; Commercial Facilities; Communications; Critical Manufacturing; Dams; Defense Industrial Base; Emergency Services; Energy; Financial Services; Food and Agriculture; Government Facilities; Healthcare and Public Health; Information Technology; Nuclear Reactors, Materials, and Waste; Transportation Systems; Water and Wastewater Systems. The list of critical infrastructures and key assets remains open and may be extended as risks and threats evolve.

NATO has largely adopted the US model and has paid particular attention to all identified categories of critical infrastructures, in particular to their protection against military threats. According to Allied Command Operations, critical infrastructure is a nation's „infrastructure assets, facilities, systems, networks, and processes that support the military, economic, political, and/or social life on which a nation and/or NATO depends" (Bearse 2021, 10). These include all the vital components of security, governance, public health and safety, the economy and the level of public confidence, incapacity or destruction of which could seriously affect a country's ability to function effectively.

The European Union has also taken important steps to address critical infrastructure issue. According to the European definition, critical infrastructure include "physical resources, services, and information technology facilities, networks and infrastructure assets which, if disrupted or destroyed, would have a serious impact on the health, safety, security or economic well-being of Citizens or the effective functioning of governments" (European Commission 2005, 20). The results of the debate on critical infrastructure protection were presented in the European Programme for Critical Infrastructure Protection (European Commission 2006), a framework document defining EU options to prevent terrorist attacks, cyber attacks and misinformation, force training, launch specific responses to protect Europe's critical infrastructure. The package of specific measures aims to improve the protection of critical infrastructures in Europe, in all EU Member States and in all relevant sectors of economic and social activity.

\section{Space systems development}

Since the first launch of intercontinental ballistic missiles and the Sputnik satellite (the 1950s), there have been concerns about the possibility of launching an arms race into outer space by the main actors - the United States and Russia. The Outer Space Treaty (United Nations Office for Outer Space Affair 1966), supplemented by the Moon Agreement (United Nations Office for Outer Space Affairs 1979), laid the groundwork for slowing down or at least limiting the pace of space militarization by banning 111 signatories from carrying nuclear or any other kinds of weapons of mass destruction in orbit around the Earth and the Moon, install such weaspons on the surface of the Moon and other celestial bodies, or station such weapons in outer space in any other manner.

At present, space systems encompass a number of aspects, from the ability of a space asset to accomplish a mission to the ability of terrestrial-based asset to accomplish a mission in or through space or the ability of a space asset to contribute to a mission from seabed to the space domain (Joint Chiefs of Staff 10 April 2018, GL-6). The most important space systems (Sellers 2015) that can be used both peacefully, for civil and commercial purposes, and in the military field are: communications satellites (voice communications, satellite television, broadband internet, mobile services and data transfer services); intelligence, surveillance and reconnaissance satellites (remote sensing data, including data on land, sea and Earth's atmosphere); navigation satellites (positioning, navigation and synchronization data); science 
satellites, stations and probes (exploration, research and experiments); command and control architecture (how users control and communicate with satellites or terrestrial systems); space launch facilities (ability to deliver useful tasks in space); government agencies, companies and universities (advanced research and development capabilities and technological implementation), etc.

Space research seems to have booming lately, and private companies and some states have set bold goals to explore the near universe, improve terrestrial life, and increase security and resilience to space phenomena that could threaten Earth. Thus, the space sector is in a new stage of development, technological innovations and new space systems are emerging, from microsatellites to constellations of hundreds of satellites, small launchers, broadband internet and Internet-of-Things (IoT), manned commercial flights and so on. However, despite predictions in the 2000s about the progress of rockets and launch and deployment technology, change has been slow. Thus, the costs per kilogram of payload placed into orbit remained similar to those of Saturn rockets and the Apollo program (late 1960s and early 1970s). Much more progress could be made in the near future, as reusable SpaceX and Blue Sky rockets could reduce costs by approximately 50-75\%. (O’Hanlon September 2018, 19).

Over the past five years, we have witnessed the rapid expansion of public services and products using satellites and related technologies, such as communications, satellite television services, or geospatial products. On September 1, 2021, the situation of operational satellites currently in orbit around Earth was as follows: US - 2.788 satellites, China - 431, Russia - 167, other countries - 1.164 (UCS Satellite Database 2021).

Table no. 1: Number of launches and satellites in 2021 (UCS Satellite Database 2021) (Kyle 2021)

\begin{tabular}{|c|c|c|c|c|c|c|c|}
\cline { 2 - 8 } \multicolumn{1}{c|}{} & US & China & Russia & India & UK & Germany & France \\
\hline $\begin{array}{c}\text { No. of } \\
\text { orbital } \\
\text { launches }\end{array}$ & 43 & 55 & 25 & 2 & - & \multicolumn{2}{c|}{6 (Europe) } \\
\hline $\begin{array}{c}\text { No. of } \\
\text { satellites }\end{array}$ & 2.788 & 431 & 167 & 61 & 347 & 47 & 31 \\
\hline
\end{tabular}

A newer trend is the use of microsatellites, especially in commercial and civil areas, in the area of Earth observation, remote communications and weather forecasting. Armed forces could use this technology to create more resilient and less vulnerable communications networks to anti-satellite weapons or to continuously track larger ground objects, such as intercontinental ballistic missiles. The Russian test of a direct-ascent anti-satellite weapon, destroying one of its own low-earth orbit space objects, a defunct satellite (Raju 2021), demonstrates the very real threat to space systems.

It is true that space power refers to the means of deterring, defeating, destroying and, in some cases, denying access to space for military or civilian purposes to potential adversaries, and space systems provide critical combat capabilities with the possibility of producing effects far superior to those on land, air or sea. Space is a new dimension of the modern warfare in which the great powers seek to develop new military capabilities in order to strengthen their national security. The growing importance of space for security has also led many countries to consider the need to develop their own counterspace capabilities - whether cybernetics, targeted weapons, electronic warfare, anti-satellite missiles, potentially offensive orbital systems and so on - which can be used to deceive, disrupt, deny, degrade, or destroy an adversary's space systems or services (Joint Chiefs of Staff 10 April 2018) (Weeden și Sanson (eds.) April 2021). 
STRATEGIES XXI International Scientific Conference

The Complex and Dynamic Nature of the Security Environment

\section{The role and place of space systems as critical infrastructure}

The designation of spatial systems as critical infrastructure depends primarily on the extent to which such systems and assets are so vital to a country that their incapacity or destruction could seriously affect the national security, economic security, the public health and safety or any combination thereof. Therefore, experts should establish the degree of dependence of different areas of activity of the economy and society on the specific services and products offered by these space systems.

Space systems and assets have become indispensable for the efficient functioning of various applications and services in the civil (commercial and scientific) and military fields or the protection of Earth from meteoroids and space debris. The malfunctioning of space systems can have detrimental consequences for industry and agriculture, the energy sector, transport, banking and financial system, military operations, government activities and therefore the well-being and security of the population. For example, the banking sector uses Global Positioning System (GPS) to time-stamp the financial transactions, precision agriculture uses space systems to assess the existence of variables, such as status of soils, planting density, fertilizer spreader, crop yield estimation, and other applications including rail traffic control, highway traffic management, commercial aviation and maritime navigation depend on satellites for location and operational safety (Piso 2015, 15). The economy and energy systems also depend on the proper functioning of space systems for resource mapping services, management of pipelines and other industrial facilities, and vital services, such as supply of energy and drinking water, information and communication technologies and even waste management depend directly on them.

Last but not least, space and space technologies are a topic of great interest to military planners, given that the operating environment will be characterized in the near future by the innovation and operationalization of capabilities specific to new areas of military operation (cyberspace and outer space) (Romanian Ministry of National Defence 2021, 9). Therefore the space systems must be considered from a dual perspective - both the advantages of these technologies in the civil and military spheres, as well as the potential threats and risks to national security. They are a key factor in gaining superiority on the battlefield and should be integrated into all joint operations, both as a facilitator and as a force multiplier.

Undoubtedly, space systems are essential and affect the functionality of other critical infrastructure sectors. Space assets are critical because they are part of the various applications and systems that affect everyday life and national security, from satellite television, GPS systems, and the constellation of satellites that will provide worldwide broadband internet, to high-speed communications and early warning of ballistic missile attacks. In fact, thousands of low-orbit Earth satellites will help develop new 5G networks, large-scale information infrastructures and global connectivity to IoT.

The most recent assessments of the US Intelligence and National Security Alliance have identified several reasons why space systems should be designated as the $17^{\text {th }}$ critical infrastructure sector. For example, in support of national security, commercial satellites have detected new intercontinental ballistic missile sites in China, provided valuable information to disaster response actions, and found some signs of potential collisions along the India-Pakistan border, tracked piratery, poaching and illegal fishing activities (Intelligence and National Security Alliance November 2021, 4). Other possible missions of commercial geospatial systems relate to space imaging, intelligence gathering, disaster prevention and preparedness, search and rescue, weather forecasting, communications.

The designation of space systems as a new category of critical infrastructure will facilitate access to space and increase the security and resilience of key space systems, adding protection to production and supply chains for others satellites, spacecraft and components, 
while extending existing protections for communications satellites to their launch and mission systems (Space Foundation 2021, 4). This would open up new opportunities (Swallow și Visner 2021) such as: promoting and strengthening collaboration in the space industry, on the one hand, and between industry and government authorities, on the other (more specifically between manufacturers, suppliers, owners and operators); developing basic space and counterspace systems; fostering the achievement of a global consensus on the essential nature of space assets and the need to protect and support them; identifying and developing a system for assessing threats and risks to space systems; and accelerating the adoption of best standards, practices and technologies for securization and resilience of space systems.

The US has already taken the first steps in the process of designating the space systems as a critical infrastructure sector (Waterman 2021), given the fact that dependence on space assets is greater than ever before and access to space is vital to the national and economic security, whether we're talking about the United States and its allies, or China, Russia and India.

\section{Conclusions}

Today, the space environment is particularly complex and dynamic, consisting of civil, commercial and military systems on which we are increasingly dependent. No country that wants to expand its economy and strengthen its national security can ignore outer space and space systems as a source of data and information, a channel of communication and an area of potential risks and threats. Competitive advantage is about adapting to new strategic challenges by developing new sophisticated space systems and technologies, in which satellites are, if necessary, tools for multiplying forces - continuous global coverage, low vulnerability, autonomous operations - and can provide essential secure communication about weather conditions, navigation data and possible threats.

Space systems are therefore critical due to their place and the role they play in the stability and functionality of the political, economic, social and military system system, by the degree of exposure to certain disruptive factors, but also by the variable set of their vulnerabilities to threats that directly or indirectly target them. Under these conditions, the designation of space systems as a new sector of critical infrastructure becomes mandatory, so that states and regional organizations can coordinate policies, strategies, programs or resources in support of these space systems and set clear security and resilience standards for them.

\section{BIBLIOGRAPHY:}

BEARSE, Ronald S. 2021. "An Overview of Critical Infrastructure, its Importance, and Key Policy Terms." Terrorism Experts Conference "The Military Role in Countering Terrorism". Edited by NATO Centre of Excellence Defence. Ankara, Turkey, October 12-13. Accessed November 19, 2021. https://www.tmmm.tsk.tr/TEC2021/ presentation/Ronald\%20BEARSE.pdf

European Commission. 2006. Communication from the Commission on a European Programme for Critical Infrastructure Protection. Brussels, December 12. Accessed November 19, 2021. http://eur-lex.europa.eu/LexUriServ/LexUriServ.do? uri=COM:2006:0786:FIN:EN:PDF

European Commission. 2005. Green Paper on a European Programme for Critical Infrastructure Protection. Brussels, November 17. Accessed November 19, 2021. https://eur-lex.europa.eu/legal-content/EN/TXT/PDF/?uri=CELEX:52005 DC0576\&from $=\mathrm{EN}$ 
STRATEGIES XXI International Scientific Conference

The Complex and Dynamic Nature of the Security Environment

Intelligence and National Security Alliance. November 2021. "Designating the U.S. Space sector as Crtical Infrastructure." Accessed December 15, 2021. https://www.insaonline. org/wp-content/uploads/2021/11/INSA_WP_Space_v3.pdf

Joint Chiefs of Staff. 10 April 2018. "Space Operations." Joint Publication 3-14.

KYLE, Ed. 2021. "Space Launch Report." 2021 Launch Vehicle/Site Statistics. December 31. Accessed January 5, 2022. https://spacelaunchreport.com/log2021.html

O’HANLON, Michael. September 2018. Forecasting Change in Military Technology, 20202040. Foreign Policy at Brookings.

PISO, Marius-Ioan. 2015. "Infrastructurile critice spațiale: introducere în securitatea planetară." Prelegere cu prilejul decernării titlului de Doctor Honoris Causa Scientiarum al Universităţii de Vest din Timişoara. December 10.

RAJU, Nivedita. 2021. Russia's anti-satellite test should lead to a multilateral ban. Edited by SIPRI. December 7. Accessed December 17, 2021. https://www.sipri.org/ commentary/essay/2021/russias-anti-satellite-test-should-lead-multilateral-ban

Romanian Ministry of National Defence. 2021. "Strategia Militară a României (Military Strategy of Romania)." Bucharest.

SELLERS, Jerry Jon. 2015. Understanding Space: An Introduction to Astronautics. Fourth Edition. New York: McGraw-Hill Companies.

Space Foundation. 2021. "The Authoritative Guide to Global Space Activity." The Space Report, Space Foundation.

SWALLOW, Edward, and Samuel Visner. 2021. "It's time to declare space systems as critical infrastructure." Politico. February 4. Accessed November 25, 2021. https://www.politico. com/news/2021/04/02/its-time-to-declare-space-systems-as-critical-infrastructure478848

The White House. 2003. Homeland Security Presidential Directive/Hspd-7 - Critical Infrastructure Identification, Prioritization, and Protection. December 17. Accessed November 17, 2021. https://georgewbush-whitehouse.archives.gov/news/ releases/2003/12/20031217-5.html

The White House. 2013. Presidential Policy Directive/PPD-21 - Critical Infrastructure Security and Resilience. February 12. Accessed November 17, 2021. https://obamawhitehouse.archives.gov/the-press-office/2013/02/12/presidential-policydirective-critical-infrastructure-security-and-resil

The White House. 2003. The National Strategy for the Physical Protection of Critical Infrastructure and Key Assets. February. Accessed November 17, 2021. https://www.dhs.gov/xlibrary/assets/Physical_Strategy.pdf

2021. UCS Satellite Database. September 1. Accessed October 12, 2021. https://www.ucsusa.org/resources/satellite-database

United Nations Office for Outer Space Affair. 1966. "Treaty on Principles Governing the Activities of States in the Exploration and Use of Outer Space, including the Moon and Other Celestial Bodies." December 19. Accessed November 16, 2021. https://www.unoosa.org/oosa/en/ourwork/spacelaw/treaties/introouterspacetreaty.html

United Nations Office for Outer Space Affairs. 1979. "Agreement Governing the Activities of States on the Moon and Other Celestial Bodies." December 5. Accessed November 16, 2021. https://www.unoosa.org/oosa/en/ourwork/spacelaw/treaties/intromoon-agreement. html 
US Congress. 2001. "Uniting and Strengthening America by Providing Appropriate Tools Required to Intercept and Obstruct Terrorism (USA Patriot Act) Act of 2001." Public Law 107-56. October 26. Accessed November 17, 2021. https://www.congress. gov/107/plaws/publ56/PLAW-107publ56.pdf

US Department of Defense. January 2011. "National Security Space Strategy."

US Office of Homeland Security. 2002. National Strategy for Homeland Security. July 16. Accessed November 17, 2021. URL: https://www.dhs.gov/sites/default/ files/publications/nat-strat-hls-2002.pdf

WATERMAN, Shaun. 2021. DHS Weighs How to Protect Increasingly Critical Space Systems. Edited by Via Satellite. November 19. Accessed December 16, 2021. https://www.satellitetoday.com/cybersecurity/2021/11/19/dhs-weighs-how-to-protectincreasingly-critical-space-systems/

WEEDEN, Brian, and Victoria Sanson (eds.). April 2021. Global Counterspace Capabilities: An Open Source Assessment. Secure World Foundation. 